\title{
Instant Messenger Friends? Social Relationship Behavior Differences Between Two Countries
}

Charles M. Hermans, Missouri State University, USA

Diana L. Haytko, Florida Gulf Coast University, USA

Erika Matulich, University of Tampa, USA

Kevin J. Shanahan, Mississippi State University, USA

\begin{abstract}
Canadian and U.S. respondents' social behavior resulting from communication tools is examined. Results suggest that Canadians are less likely to use social communication tools to develop new relationships.
\end{abstract}

Key Terms: consumer behavior, instant messaging, social relationship seeking, internet

\section{INTRODUCTION}

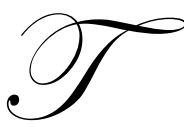

he Internet has enabled people to communicate around the world effortlessly, instantaneously and at minimal cost. This new technology has increased communication across cultures. With the Internet, many new forms of interpersonal communication such as email, instant messaging, chat rooms, and bulletin boards have emerged. These improved communication capabilities give the appearance that the world is "shrinking" in the sense that individuals can communicate virtually cost free and effortlessly across nations. However, despite the availability of this new technology, not all Internet users in all countries have the same attitude towards these modes of communication. The purpose of this study is to examine the initiation of social relationships online via Instant Messenger and whether differences exist between Canadians and Americans. These two countries are of interest because, as similar as they are, cultural differences exist that may influence openness to online interactions and relationship development.

\section{BACKGROUND}

Two issues should influence the results of this exploratory research: Internet penetration and use by country and cultural factors that may influence interest in establishing online relationships. Worldwide, Internet usage has grown exponentially. Gerlsbeck (2007) reported that Canada leads the world in Internet use. Despite it's small population, it has the $9^{\text {th }}$ highest number of Internet users age 15 and older, with 21 million people online according to March 2007 data. Canadians also spend more time online than anyone else: 39.6 hours per month on average, which is eight hours more than the U.S., which is $4^{\text {th }}$. However, Canadians are using the Internet somewhat differently than Americans. E-Commerce has not grown as much in Canada, as Canadians spend less money each year online. Also, mobile Internet penetration remains quite low in Canada (Gerlsbeck 2007).

From a cultural perspective, some people may not be as willing to try out new forms of communication technology because it does not promote the foundations on which strong social relationships are born. For example, when information is not communicated face to face, it can increase the psychological distance between interacting people (McQuillen, 2003). Oral communication allows for non-verbal cues which enhance the receivers understanding of the information conveyed. While video chat is gaining popularity, the predominance of communication on the Internet does not allow for these non-verbal cues. 
Communication online has been referred to as hyperpersonal communication (Henderson and Gilding, 2004). In computer-mediated communication, people can choose to reveal as much or as little as they want. This introduces an element of risk in interpersonal relationship development as computer users must accept the risk of rejection in order to openly and honestly share personal information. In the case of adolescents, however, it would appear that the risks associated with communicating online are not an issue. According to results from the American Youth Internet Safety Survey, 25\% of the respondents reported casual online friendships and $14 \%$ reported a close online friendship (Wolak, et al., 2002). According to results from the Pew Internet and American Life Project, 74\% of online teens use Instant Messenger, and 68\% use it at least several times a week (Gross, Juvonen and Gable 2002). Almost one-fifth of teens use it as the as the most frequent method of contacting their friends (Green et al 2005). While adults and adolescents alike are found to be avid users of instant messaging and other computer mediated communication tools, perhaps the younger generation is embracing it to a greater extent.

Computer mediated communication is a growing pastime. Instant messaging is also growing. One instant messaging service, ICQ, boasts over 190 million users worldwide ("ICQ.com," 2005). Teens are avid text messengers, but when online, IM is the contact method of choice (Green et al. 2005). Gennaro and Dutton (2007) explored the degree to which people use the Internet to make friends, and thereby, reconfigure their social networks. They found that approximately 20 percent of Internet users have met new friends online, and about half of the individuals go on to meet one or more of these virtual friends in person. Interestingly, past research has not found gender differences in self-disclosure in online relationships (Cho 2007; Barak and Gluck-Ofri 2007). However, one study did find that females tend to be more reciprocal than male respondents in self-disclosure (Barak and GluckOfri 2007).

The idea that many people from across the planet are involved in online communities suggests that cultural differences might play a role in online communications. To examine the way social relationships are developed online via instant messaging, attitudes toward online communication generally should be addressed. Specifically, how open are people to online relationships. Are there cultural differences in the way relationships are formed? Some studies suggest this might be the case. A study by Ebert, et. al. (2003), for example, examined dialectical theory comparing openness and closedness, finding that American's openness was one of the major themes that contributed to social experiences. The study examined immigrants from 27 countries across the globe contrasting them to Americans. The results suggested many people from other countries found American openness to be conflict with their own culture. An example from this study included an Iranian Male who said, "I was taught that you cannot trust American girls, they are so open, because we are coming from a conservative society." Another subject, an Indian student had this to say about communication with respect to employment, "...But here I was much more free and liberal...we just talk like this. It's nothing wrong, but if I go back again home, I would be very hesitant again to talk like that." These statements depict the conflict between openness and closedness in relation to social experiences. Such statements may be indications of differences in social relationship development behavior across national boundaries. This study examines differences in social communications resulting from the use of instant messaging tools in two countries, the United States and Canada.

\section{METHODOLOGY}

To examine social relationship seeking behavior using instant messengers across cultures, a sample of online computer users was needed to participate in our study. The respondents were all from North America, and were selected in a stratified selection process from an instant messaging service database. The participants email addresses were publicly self-published along with other contact information. Respondents were geographically stratified to gain a more general sample, which included 20 major cities in the U.S. and Canada. A stratified sampling process was employed in an attempt to obtain a geographically diverse set of respondents who, in aggregate, would be more representative of the countries as a whole.

The online survey was administered using Perseus Survey Solutions for the Web. Respondents were contacted by email and provided with an invitation to participate in the study and instructions to respond by clicking on a hyperlink taking them to the survey page. Of the 140 surveys returned, four had an insufficient number of responses to be used and were discarded for a total of 134 responses. The sample included 76 Canadians and 58 Americans. While a disproportionate number of male $(n=100)$ and female $(n=26)$ respondents participated, Internet 
users are typically characterized as being predominantly male. Sixty-seven percent of the sample is in the 19-35 age category, and fifty-one percent of the sample had been using the Internet for 5 years or longer.

To measure the initiation of social relationships on the Internet, we developed a new four-item scale. No current scales exist to measure online relationship seeking behavior. This scale was pre-tested with a group of 47 college students who are active Internet users. Scale reliability for the pre-test resulted in a coefficient alpha of .754 (Cronbach, 1951). Thus, the scale was determined suitable for further examination. The scale was measured using a 7-point Likert-type scale, ranging from "strongly agree" to "strongly disagree." Scale items and descriptive statistics for the sample are provided in Table 1. Cronbach's alpha (1951) was used to examine reliability. To examine convergent and discriminant validity, factor analysis was employed. The factor structure for the scale reveals a unidimensional multi-item measure. Factor loadings, eigenvalues, and coefficient alpha are also included in Table 1.

To examine demographic characteristics associated with the Internet relationship seeking construct in each country, the sample was first divided between U.S. and Canadian respondents. Chi-square statistics revealed differences between the U.S. and Canadian respondents for income, length of time on the Internet, and ethnicity all will significance at $\mathrm{p}<.01$. The Chi-square tables are reported in Table 2.

Table 1: Internet Relationship Seeking Scale Item Analysis

\begin{tabular}{|c|c|c|c|}
\hline $\begin{array}{l}\text { Item } \\
(\text { eigenvalue }=2.66, \text { explained variance }=66.54 \%, \text { coefficient alpha }=.823)\end{array}$ & $\begin{array}{c}\text { Mean } \\
(\mu)\end{array}$ & $\begin{array}{l}\text { S.d. } \\
(\sigma)\end{array}$ & $\begin{array}{l}\text { Factor } \\
\text { Loading }\end{array}$ \\
\hline IRS3. I usually talk to anyone I can using instant messaging. & 4.059 & 1.82 & .917 \\
\hline IRS2. I talk to people all over the world using instant messaging. & 4.776 & 2.01 & .713 \\
\hline IRS4. I am willing to talk to people I do not know using instant messaging. & 3.779 & 2.42 & .705 \\
\hline $\begin{array}{l}\text { IRS1. I have a lot of people on my instant messaging contact list that I have never met in } \\
\text { person. }\end{array}$ & 3.529 & 1.93 & .648 \\
\hline
\end{tabular}

Table 2: Chi-Square Comparisons - Canada vs. U.S.

\begin{tabular}{|l|c|c|}
\hline & Canada & U.S. \\
\hline Income $^{2}$ & \multicolumn{2}{|c|}{$\chi^{2}=15.09, \mathrm{n}=119, \mathrm{df}=3, \mathrm{p}<.002$} \\
\hline$<\$ 20,000$ & 42 & 20 \\
\hline$\$ 20,000$ to $\$ 70,000$ & 30 & 26 \\
\hline$>\$ 70,000$ & 2 & 12 \\
\hline Length of Time using the Internet $^{2,3}$ & $\chi^{2}=13.34, \mathrm{n}=121, \mathrm{df}=3, \mathrm{p}<.004$ \\
\hline$<1$ year & 4 & 0 \\
\hline $1-2$ years & 10 & 6 \\
\hline 2-5 years & 32 & 12 \\
\hline 5 years + & 30 & 40 \\
\hline Ethnicity & $\chi^{2}=11.99, \mathrm{n}=106, \mathrm{df}=1, \mathrm{p}<.001^{1}$ \\
\hline Caucasian & 50 & 24 \\
\hline Minority & 10 & 22 \\
\hline
\end{tabular}

Note: Percentages represent line items only.

${ }^{I}$ Fisher's Exact Test for a $2 \times 2$ table.

${ }^{2}$ Caution should be exercised when interpreting Chi-square statistics where cell values are less than 5.

${ }^{3}$ Degrees of freedom include a category for unanswered cells.

Next, the sample was divided between "Internet Relationship Seekers" and "Non- Internet Relationship Seekers." Internet relationship seekers are those who reported a grand mean of greater than 4 on the 4-item Internet relationship seeking scale. Likewise, Non- Internet relationship seekers are those who reported a grand mean less than 3 on the scales. Chi-square analysis in Table 3 indicates significant differences between countries and gender at $\mathrm{p}<.01$ and with ethnicity at $\mathrm{p}<.05$. 
Table 3: Chi-Square Comparisons: Internet Relationship Seekers

\begin{tabular}{|c|c|c|}
\hline & \multicolumn{2}{|c|}{ Internet Relationship Seekers } \\
\hline Country & $\chi^{2}=9.68, \mathrm{n}=121, \mathrm{df}=1, \mathrm{p}<.002^{1}$ & 42 \\
\hline Canada & 28 & 18 \\
\hline United States & 38 & 40 \\
\hline Gender & $\chi^{2}=.11 .28, \mathrm{n}=126, \mathrm{df}=1, \mathrm{p}<.001^{1}$ & 40 \\
\hline Female & 6 & \\
\hline Male & 60 & 38 \\
\hline Ethnicity & $\chi^{2}=5.31, \mathrm{n}=98, \mathrm{df}=1, \mathrm{p}<.021^{1}$ & 8 \\
\hline Caucasian & 32 & \\
\hline Minority & 20 & \\
\hline
\end{tabular}

Note: Percentages represent line items only.

${ }^{1}$ Fisher's Exact Test for a $2 \times 2$ table.

${ }^{2}$ Caution should be exercised when interpreting Chi-square statistics where cell values are less than 5.

${ }^{3}$ Degrees of freedom include a category for unanswered cells.

Finally, differences in Internet Relationship Seeking Behavior were examined using a multivariate t-test. The result shows significant differences between the U.S. and Canada for Internet Relationship Seeking via instant messaging (Hotelling's $\mathrm{T}^{2}: \mathrm{F}=3.88$; $\mathrm{df}=4,127 ; \mathrm{p}<.005$ ). Results of the independent $\mathrm{t}$-tests for each of the 4 items in the "Internet Relationship Seeking" scale are reported in Table 4, and show significant differences between the U.S. and Canada for all four items at $\mathrm{p}<.05$.

Table 4: T-tests

\begin{tabular}{|c|c|c|c|c|}
\hline Item & $\begin{array}{l}\text { Mean Difference } \\
\text { (U.S. - Canada) }\end{array}$ & $\mathbf{F}$ & df & p - value \\
\hline $\begin{array}{l}\text { IRS1. I have a lot of people on my instant messaging contact list } \\
\text { that I have never met in person. }\end{array}$ & .9879 & 8.79 & 1 & .004 \\
\hline IRS2. I talk to people all over the world using instant messaging. & .0815 & 5.27 & 1 & .023 \\
\hline IRS3. I usually talk to anyone I can using instant messaging. & .9646 & 9.47 & 1 & .003 \\
\hline $\begin{array}{l}\text { IRS4. I am willing to talk to people I do not know using instant } \\
\text { messaging. }\end{array}$ & 1.439 & 12.40 & 1 & .001 \\
\hline
\end{tabular}

\section{DISCUSSION}

The results suggest significant differences exist between Canadian and U.S. instant messenger users. There are also considerable differences demographically between relationship seekers and non-seekers. Comparisons of the U.S. and Canadian samples reveal that a higher percentage of higher income instant messenger users are represented in the US sample. There are more users who have used the Internet for 5 years or longer in the U.S. There are also more minorities represented in the US sample, although this might be expected based on minority demographics for the two countries. The differences in the demographic profile of the relationship seekers and nonseekers also revealed a stark contrast. Relationship seekers are more likely in the U.S., male and minority, whereas the non-seekers are more likely in the Canadian group, female, and Caucasian.

The relationship seeking scale revealed a unidimensional measure which appears to converge on the construct with consistently high factor loadings. When this scale is compared across the two countries, a significant and consistent result is found across all measures. The U.S. respondents consistently reported a higher level of agreement with all 4 of the relationship seeking scale items.

The results suggest that Americans are more willing to use instant messenger to try to develop relationships with people they don't know than their Canadian counterparts. Therefore, Americans may be more likely to enter into social relationships on the Internet generally. However, this construct should be tested via other modes of Internet communication. Members of dating services, chat users, and bulletin board users may be potential sample 
groups. As instant messaging continues to grow and become more and more popular around the world, we might expect cross cultural mutations in differences over time as more people embrace the diverse communication opportunities on the Internet.

\section{CONCLUSION}

Studying intercultural communication practices has provided valuable information for scholars and lay people alike for many years. The information found in this study can be useful to marketers in many ways. From the survey it is obvious that Americans are willing to converse with strangers using instant messaging. Marketers can use instant messaging and other computer mediated communication tools to convey information, target advertising or conduct research. What this survey does not explain is specific reasons as to why Canadians are less likely to communicate with people they do not know online. Further research may indicate factors, other than the cultural indications found in this study, which might provide a better indication of why these differences exist. Perhaps the fact that Americans have also been using the Internet longer would explain some of this difference. Further research may also create an understanding as to why American culture is so much more open and willing to communicate freely with people they do not know online.

\section{AUTHOR INFORMATION}

Charles Hermans is an Associate Professor of Marketing at Missouri State University teaching international marketing. He earned is Ph.D. from New Mexico State University.

Diana Haytko is an Associate Professor of Marketing at Florida Gulf Coast University. She earned her Ph.D. from the University of Wisconsin-Madison.

Erika Matulich is an Associate Professor of Marketing in the John H. Sykes College of Business at the University of Tampa as well as the Program Director for the Masters in Science in Marketing. She earned her Ph.D. from the University of Wisconsin-Madison and is also a Professional Certified Marketer.

Kevin J. Shanahan (PhD, New Mexico State University) is an Assistant Professor of Marketing at Mississippi State University. His research has appeared in Journal of Advertising, the Journal of the Academy of Marketing Science, Journal of Business Ethics, Journal of Current Issues and Research in Advertising and numerous other scholarly publications. Dr. Shanahan's research interests include, advertising strategy, non-profit marketing, aberrant online consumer behavior and public policy.

\section{REFERENCES}

1. Barak, Azy and Orit Gluck-Ofri (2007), "Degree and Reciprocity of Self-Disclosure in Online Forums," CyberPsychology \& Behavior, Vol. 10 (3), 407-417.

2. Cho, Seung Ho (2007), "Effects of Motivations and Gender on Adolescents' Self-Disclosure in Online Chatting," CyberPsychology \& Behavior, Vol 10 (3), 339-345.

3. Erbert, L., Pérez, F., Gareis, E. (2003). Turning points and dialectical interpretations of immigrant experiences in the United States. Western Journal of Communication. 67 (2), 113-137.

4. Finkelhor, D., Mitchell, K., Wolak, J. (2002). Close online relationships in a national sample of adolescents. Adolescence. 37 (147), 441-456.

5. Gennaro, Corinna Di and William H. Dutton (2007), "Reconfiguring Friendships: Social Relationships and the Internet," Information, Communication \& Society, Vol. 10 (5), 591-618.

6. Gerlsbeck, Rob (2007), “Canada’s Web,” Marketing Magazine, Vol. 112 (9), 9.

7. Green, Melanie C, Jessica Hilken, Hayley Friedman, Karly Grossman, Josephine Grasiewski, Rob Adler and John Sabini (2005), "Communication Via Instant Messenger: Short- and Long-Term Effects, Journal of Applied Social Psychology, Vol. 35 (3), 445-462.

8. Henderson, Samantha and Michael Gilding (2004) “'I've Never Clicked this Much with Anyone in My Life': Trust and Hyperpersonal Communication in Online Friendships," New Media \& Society, Vol. 6 (4), 487-506. 
9. Hofstede, Geert. "ITIM Creating Cultural Competence". 2003. July 20, 2003. www.geert - hofstede.com

10. Hofstede, Geert. Geert Hofstede's Homepage. July 21, 2004

<http://feweb.uvt.nl/center/hofstede/index.htm>.

11. Kotabe, Masaaki \& Helsen, Kristiaan. Global Marketing Management, 2ed. New York: John Wiley \& Sons, Inc., 2001.

12. McQuillen, J. (2003). The influence of technology on the initiation of interpersonal relationships. Education. 123 (3), 616-624.

\section{NOTES}

